\title{
京都市左京区山麓部の石仏の分布と石材利用
}

\section{A study on the distribution and rock types of stone statues of Buddha in the northeastern mountain-foot districts of Kyoto City}

張 平星*

\author{
Pingxing ZHANG
}

\begin{abstract}
This study focused on the distribution and rock types of wayside stone statues of Buddha in the northeastern mountainfoot districts of Kyoto City to grasp the culture of stone use in Kyoto basin. Investigations were conducted in 15 districts of Sakyo$\mathrm{ku}$ that are adjacent to the mountains. We collected the information on the location and rock types of Buddha statues, as well as the data of magnetic susceptibility by KT-10 (Terraplus). We found over 1900 Buddha statues were celebrated in 360 places that were distributed in whole areas. Buddha statues made of Shirakawa-ishi, a type of white granite quarried from the northeast of Kyoto, were celebrated in 320 places and distributed in over $10 \%$ grids when the areas were analyzed by $100 \mathrm{~m}$ mesh. Among them, 18 grids owned more than 20 statues. Shirakawa-ishi showed a stable magnetic susceptibility from 0.039 to $0.197 \times 10^{-3}$ SI. 90 Buddha statues made of other stones such as granodiorite, sandstone, and chart from the adjacent mountains were found in 68 places. The distribution area of Buddha statues made of Shirakawa-ishi has possibly expanded over the 15 distrcts, while one of the boundaries was considered in the Kurama district. To grasp the stone culture of Kyoto, further studies on the styles and construction history of Buddha statues are expected.
\end{abstract}

Keywords: stone status of buddha, stonework, Shirakawa-ishi, magnetic susceptibility, a culture of stone, Kyoto キーワード：石仏，石造物，白川石，带磁率，石の文化，京都

\section{1. はじめに}

地場の石はかつて重要な自然資源として石積みや石造物に使わ れ, 地域特有の景観を創出している。しかし近代以降, 石材の流通 は世界中に広まり，都市化により元の石積みや石造物が撤去され たり, 他産地の石材やコンクリート, 金属などに転換されたり, 地 域本来の石の景観が消失しつつある。

京都の比叠山南部に産出する「白川石」は, 京都盆地の唯一の良 質な花崗岩資源であり, 貴重な造園石材として研究されてきた 1-3)。 近年では白川石に関して, 造園材料の範疇を越え, 地域の景観形 成における役割が研究された。張らの 2018 年の調査 4 )では, 白川 石の採石産業が発達していた京都市の北白川, 一乗寺と修学院の 3 集落において，石積みと石造物の多くは白川石で作られたこと を解明した。石造物のうち, 道標と石灯籠に比心，白川石製の石仏 が多く祭られている結果がみられた。

石造美術の専門家である川勝政太郎氏の 70 年前の調査による と, 京都は比㪍山から広まった浄土信仰の強い影響により, 鎌倉 期から室町期までの作とみられる花崗岩製の阿弥陀如来坐像が多 いのが特色である。これらの石仏の中, 高さ $50 \mathrm{~cm}$ 以内の小さい ものが町内に「お地蔵さま」と称して祭られることが多い5)。しか しその石材は白川石であるかを判別した研究が見当たらない。 その一方, 京都盆地を囲む山から花崗閃緑岩, 砂岩, チャート, 頁岩, ホルンフェルスなど多様な岩石の採取があり, 京都の古庭 園に利用されていた 6)。京都では白川石以外の岩石資源の採取と 利用もあったことから, 白川石の産地以外の山麓部では, それぞ れの地場の石を使って石仏を製作した可能性は否定できない。ま た, 江戸時代以降, 全国の石材の流通が盛んになり, 京都盆地外の 石で作られた石仏が存在する可能性は否定できない。

地場の石で作られた石積みや石造物が消失している今日, 石仏 は地域住民の信仰心が集り, かつ移設可能であるため, 都市化の 中で比較的に継承されやすい景観要素である。道沿いに祭られる 石仏の石材を切口として，石の文化の一端を捉えることができよ
う。京都の路傍に祭られる信仰物は民俗学，考古学および建築学 の分野で多く調査されている 7-12)が, その調査内容は信仰物の種類, 地蔵盆の実施方法，祠の立地などであり，石仏の石材への注目は なかった。また, 調査範井は京都の中心部8-11)や南東部8,12)であり,

白川石の産地を含む京都市北東部の山麓部に及ばなかった。

そこで本研究は京都盆地の石の文化の一端を捉えることを目指 し，京都市左京区山麓部の石仏の悉皆調査に基づき，路傍に祭ら れている石仏の分布と石材の種類を解明することを目的とした。

\section{2. 研究方法}

\section{（1）調査エリアの設定}

京都市左京区の中で, 大原, 鞍馬, 静市などの京都盆地の北の小 盆地や，比㕡山地から分離して孤立丘となった吉田山と黒谷に隣 接する地域を含め，山に隣接する地域をすべて調查範囲とした。

京都の路傍祠は, 明治初期の廃仏棄釈により一旦廃絶したが, 明 治末期から復活した 11,13)ことにより，明治大正時代の集落範囲を 参考にした。現在の左京区の山麓部は，明治時代に成立した愛宕 郡の一部が昭和前期に編入されたものであり，旧村名や旧大字名 を冠称する町が多い。そこで各集落の所有地が左京区に編入され た経緯 14)を参考し，現在の町の区画をもとに調査範囲を南の南禅 劸ら北の大原までの 15 エリアを設定した（表一1）。

\section{(2) 石仏の安置場所に関する事前把握}

路傍に祭られる信仰物の分布に関わる既往研究では，小範囲に おいて直接に現地踏査で確認する方法 $4,9,11)$ と，大範囲において地 図の路傍祠の記号に基づき現地調査を行う方法 10,15)がみられる。 本研究は調査範囲が広いため, 地図の路傍祠の記号と Google Maps を用いて事前把握し, 現地調査で確認や追加を行うことに より, 路傍の石仏を満遍なく調査した。まず京都市基本図 (1/2500, 平成 20 年 28 年発行) およびゼンリン住宅地図 (京都市左京区, $1 / 1500,2019$ 年 8 月発行) に記載されている路傍祠の記号を判読 し, 現地調査の確認対象とした。次に, Google Mapsに登録され

\footnotetext{
*東京農業大学地域環境科学部造園科学科
} 
表一1 本研究の調査範囲となる 15 エリア

\begin{tabular}{|c|c|c|c|c|}
\hline $\begin{array}{l}\text { 明治時代 } \\
\text { の集落名 }\end{array}$ & 現左京区に対応する範囲 & \multicolumn{2}{|c|}{$\begin{array}{l}\text { 本研究の } \\
\text { エリア }\end{array}$} & $\begin{array}{l}\text { 山間部を } \\
\text { 除く面積 }\end{array}$ \\
\hline 大原村大原 & 「大原」を冠称する 13 町 & 1 & 大原 & 236 ha \\
\hline 八瀬村 & 「八瀬」を冠称する 4 町 & 2 & 八瀬 & 68 ha \\
\hline 鞍馬村 & 「鞍馬」を冠称する 3 町 & 3 & 鞍馬 & 33 ha \\
\hline 静市野村 & 「静市」を冠称する 3 町 & 4 & 静市 & 200 ha \\
\hline 岩倉村 & 「岩倉」を冠称する 32 町 & 5 & 岩倉 & 442 ha \\
\hline 松万崎村 & 「松ケ崎」を冠称する 59 町 & 6 & 松ヶ崎 & 109 ha \\
\hline 修 高野 & 「上高野」を冠称する 53 町 & 7 & 上高野 & 118 ha \\
\hline 学 修学院 & $\begin{array}{l}\text { 「修学院」を冠称する } 55 \text { 町 } \\
\text { 「山端」を冠称する } 11 \text { 町 }\end{array}$ & 8 & 修学院 & 87 ha \\
\hline 村 一乗寺 & 「一乗寺」を冠称する 89 町 & 9 & 一乗寺 & 135 ha \\
\hline 白川村 & 「北白川」を冠称する 43 町 & 10 & 北白川 & $117 \mathrm{ha}$ \\
\hline 浄土寺村 & 「浄土寺」を冠称寸る 16 町, 他 2 町 & 11 & 浄土寺 & 61 ha \\
\hline 吉田村 & 「吉田」を冠称する 14町 & 12 & 吉田 & 117 ha \\
\hline 岡崎村 & 「岡崎」を冠称する 14 町，他 1 町 & 13 & 岡崎 & 97 ha \\
\hline 鹿谷村 & 「鹿ケ谷」を冠称する 18 町, 他 1 町 & 14 & 鹿ケ谷 & 35 ha \\
\hline 南禅寺村 & 「南禅寺」を冠称寸る6町, 他2 町 & 15 & 南禅寺 & 41 ha \\
\hline
\end{tabular}

ている「地蔵」「地蔵尊」「地蔵堂」の位置, Google ストリートビ ユー (2020 年 9 月 7 日最終参照) を用いて確認した地蔵の位置に 関する情報を収集し，現地調査の確認対象とした。

しかし上述の地図は作成上，路傍呞の記号は省略する場合が多 < 10,15)，石仏以外のものも含まれている。また，年数の経過によ り, 一部の記号が現状との不整合が予想される。なお, Google Maps の登録情報はごく一部であり, 地域によって情報量の差が 激しい。Google ストリートビューでは, 確認できない近郊部の道 が多く, 写真の角度や間隔により石仏をすべて確認するには限界 がある。以上の地図情報の限界を留意し，現地調査を行った。

\section{（3）石仏の分布と石材に関する現地調査}

事前に石仏の位置を把握した上, 最新の $1 / 1500$ 住宅地図を用い て, 2020 年 1 月〜 9 月の合計 14 日間にかけて現地調査を行った。 歩行と自転車を併用し, 道沿いを満遍なく確認した。特に旧集落 の居住域，旧街道の分岐点，公園，神社の境内，封完や墓地の入口 など，石仏を安置する確率の高、場所や事前に把握できなかった 道に注意を払って確認した。なお, 墓地の中, 非公開の寺院や個人 宅の中庭などの私有地を対象外とし, 五輪塔や石碑の一部のみが 祭られる場合は除外した。現地で新たに発見した石仏の位置を追 加し，祭られている石仏の数を記録した。

石仏の石材について, 目視とルーペで観察し, まず花崗岩と他の 石材を判別した。白川石は京都盆地を囲む山から産出する唯一の 花崗岩であり 1), その鉱物粒子の分布が均一で, 白黒が鮮明であり, また雲母が特有の光沢を持つため 3)，これらを基淮に白川石を識 別した。しかし, 風化が激しいものや土に染色されたものがあり, 結果の精度を高めるために, 補助手段として携帯型デジタル帯磁

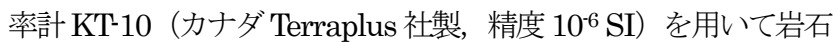
の帯磁率を測定した。帯磁率は岩石の単位体積あたりの磁性鉣物 の量を表す物理量 (単位: SI) であり, 苦鉄質鉱物の少ないチャー ト・砂岩・花崗岩が低い值, 苦鉄質鉱物の多、斑レイ岩・安山岩・ 玄武岩が高い值を示す。岩石形成時のマグマの成分によって定め られ，形成後は年月を経ってもほぼ変化しないため，石材の識別 に効果的である。測定時は凹凸の少ない面に $6.5 \mathrm{~cm}$ の測定コイル を当てると, 数秒で帯磁率の值を取得できるため, 石造物の現場 での非破壊的調查に有効な手段である 16,17)。

本研究では, 測定可能な石仏に対して, それぞれ 1 3 箇所で帯 磁率を測定した。また, 白川石の判別時の参考として, 白川石採石 場跡から採取した白川石の原石 3 個 (採取時期 : 2015 年 5 月〜 11 月）のそれぞれ 3 箇所の帯磁率を測定した。

最後に現地調査のデータを QGIS (ver. 3.4.8)に入力し, 石仏の 安置場所の分布や石仏の密集状況を分析した。

\section{15 エリアの調査結果}

15 エリアにおいて，合計 360 箇所に 1900 体以上の石仏が確認 された（図一1)。厨子に閉められたなどの原因で詳細を確認でき なかった 3 箇所以外，白川石と判断された石仏は 320 箇所あり， 全体の 9 割近く占めていた。これらはすべて一石から手彫りした ものであり，1つの石仏に複数の石材の利用がなかった。これらの 石仏から, 帯磁率の測定は 93 回行った。その結果, 帯磁率が 0.039 $\sim 0.197 \times 10^{-3} \mathrm{SI}$ の範囲にあり, 平均值 $0.125 \times 10^{-3} \mathrm{SI}$ (図一2), 標 準偏差 $0.030 \times 10^{-3} \mathrm{SI}$ であった。白川石の原石 3 個の帯磁率 $(0.070$ $\left.\sim 0.110 \times 10^{-3} \mathrm{SI}\right)$ より広い範囲の值が得られたが, 後述の花崗閃緑 岩 $\mathrm{A}, \mathrm{B}, \mathrm{F}$ と花崗岩 $\mathrm{E}$ に比べその值は顕著に低かった（表一2）。

白川石と判断された石仏が祭られる規模は，1２体から 100 体 以上，ばらつきが大きかった。その中の多くは，高さ $20 〜 40 \mathrm{~cm}$ の楕円形に近い, 荒彫りした光背付きの阿弥陀如来坐像であるが, 風化が激しく, 表情や衣紋はほとんどが識別できない(写真-1)。 その他，高さ $30 \sim 50 \mathrm{~cm}$ の双体仏や上部が山形となる細長い板碑 仏などの小石仏から，高さ $1 \mathrm{~m}$ を超える大きい阿弥陀如来坐像や 石碑に彫刻した仏像まで，造形が多様であった。

一方，白川石以外の石材と判断された石仏が 90 体，68 箇所で 確認された。これらは 1 2 体で単独に祭られているか, 白川石と 判断された石仏群に混在していた。なお, 馬頭観音や庚申塔など, 他の地域 15,18$)$ でタられる神道系の石像は確認されなかった。

\section{（1）白川石之判断された石仏の分布}

白川石と判断された石仏は, 白川石の産地となる北白川, 一乗寺 と修学院の 3 集落を超え, すべてのエリアにおいて確認された (図 -1)。100 m メッシュを作成した ${ }^{19)}$ 結果, 2448 グリッドのうち, 白川石と判断された石仏が存在するのは 257 グリッドで 1 割以上 であった (図一 3 )。1 ha に 1 2 体が確認されるのが 130 グリッ ドで約半数を占めるが，20 体を超え石仏が密集しているのが 18 グリッドあった（表一 3 )。その中，50 体を超える大規模な石仏群 が 6 箇所確認された。これら石仏群では土や草に覆われる石仏が 多いため, 石仏の数を概算とした。

エリア別にみると, 白川石の採石産業が発達していた北白川, 一 乗寺と修学院は白川石と判断された石仏の安置場所が多かった。 しかし石仏の数をエリアの面積で割ってみると，八瀬（3.81 体以 上/ha), 岡崎 (2.38 体以上/ha), 一乗寺 (1.77 体以上/ha) は上位 3 位を占めていた。また，白川石の産地から離れた八瀬，岩倉，吉 田と岡崎でも多く確認された。岩倉, 八瀬, 上高野, 一乗寺, 吉田, 岡崎の 6 エリアでは，50 体を超える大規模な石仏群がそれぞれ 1 件みられた。その一方, 白川石の産地に近い松ヶ崎では, 白川石と 判断された石仏が 7 箇所・13 体と少なかった。また，白川石の産 地から遠く離れる静市と南禅寺では白川石の石仏が少なく, 鞍馬 に入ると白川石の石仏は 3 体しかなかった。

\section{（2）白川石以外の石材と判断された石仏の分布}

松ヶ崎以外，白川石以外の石材と判断された石仏は各エリアに 散在していた。そのうち, 灰色砂岩を機械で彫り出した近代以降 の製品と判断される地蔵菩薩が多くみられた。

手彫りの石仏の石材を判別した結果（表一2），大原とそれにつ ながる八瀬と静市東部の静原地域では, 花崗岩閃緑岩 (A: 0.223〜 $0.332 \times 10^{-3} \mathrm{SI}$ と B: $7.50 \sim 11.70 \times 10^{-3} \mathrm{SI}$ の 2 種類) で作られた 12 体の石仏が確認された。そのうち，高さ $1 \mathrm{~m}$ 以上の大きい石碑仏 もあった。一方，白川石の産地から遠く離れる鞍馬と静原におい て，同じ斑レイ岩（C: $0.544 \sim 1.13 \times 10^{-3} \mathrm{SI}$ ) で作られた石仏がそ れぞれ 1 体確認された。なお, 八瀬, 岩倉, 上高野, 一乗寺, 浄土 寺, 吉田, 鹿宁谷の 7 エリアでは, 灰色，黒色，赤色の砂岩 (D: $\left.0.100 \sim 0.504 \times 10^{-3} \mathrm{SI}\right)$ の石仏 16 体が散在していた。さらに単発 事例として，鞍馬の貴船地域に白川石の帯磁率を大幅に超える花 崗岩（E: $1.51 \sim 1.80 \times 10^{-3} \mathrm{SI}$ ) の石仏 1 体，岩倉に鞍馬石（表面が 


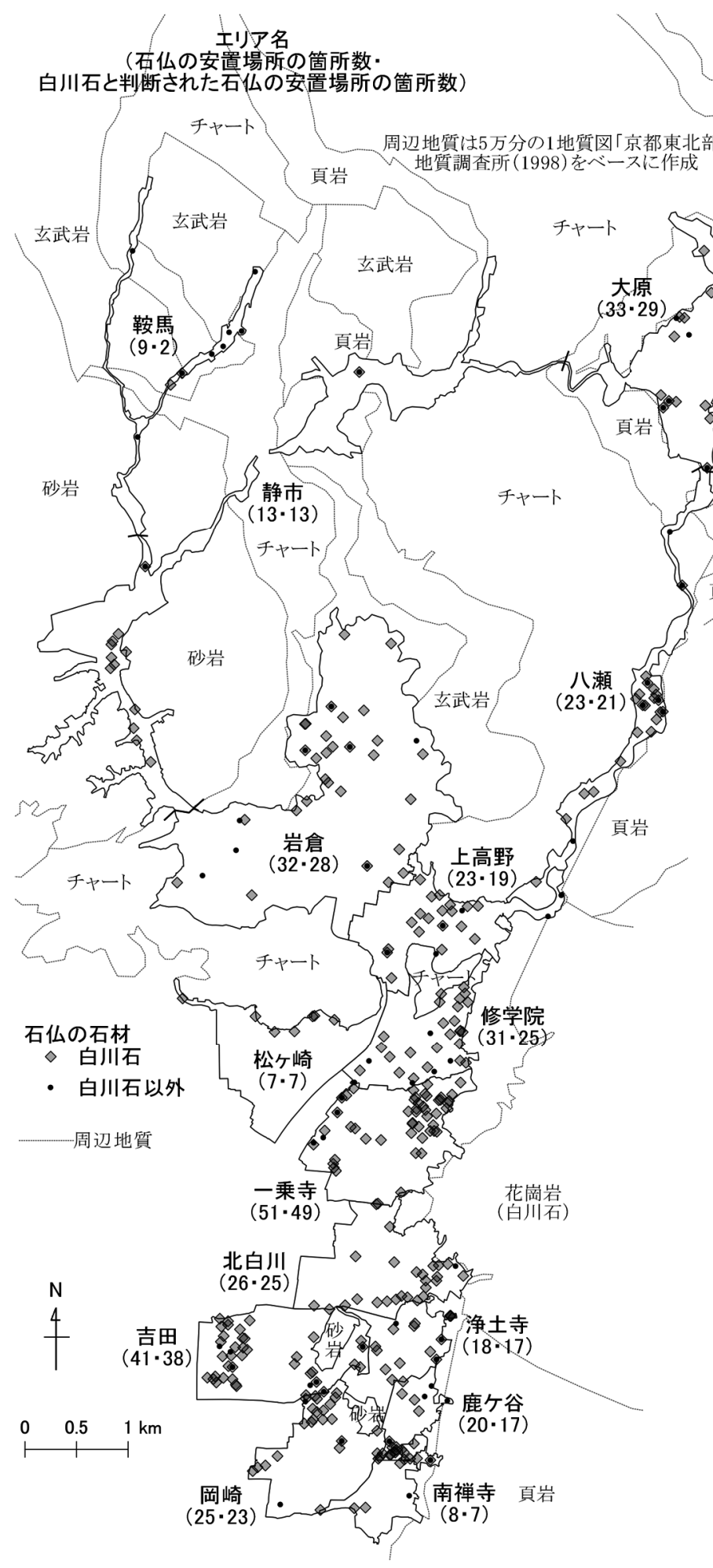

図一1石材別にみる 15 エリアの石仏の安置場所

赤茶色の花崗閃緑岩）とみられる 1 体 $\left(\mathrm{F}: 0.318 \sim 0.620 \times 10^{-3} \mathrm{SI}\right)$ と茶色のチャート (G: $\left.0.029 \sim 0.042 \times 10^{-3} \mathrm{SI}\right) 1$ 体が確認された。

\section{4. 考察}

本研究では $18.96 \mathrm{~km}^{2}$ において, 石仏が 360 箇所で祭られてい ることが確認された。他地域の民俗信仰有形物を祭る場所の密度 に比べると, 河内長野市 $109.6 \mathrm{~km}^{2}$ の 242 基（2001 年調）15)や東 京目黒区 $14.67 \mathrm{~km}^{2}$ の 54 ヶ所 (2002 年調) 19) より, 京都市左京 区山麓部の石仏を祭る場所の密度がはるかに高かった。石積みや

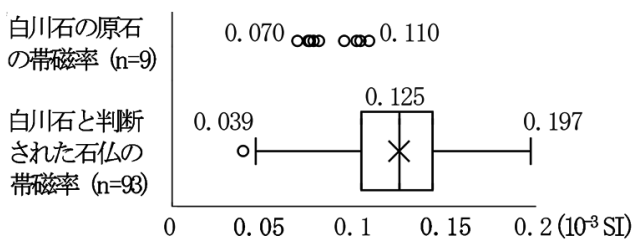

図一2 白川石と判断された石仏の帯磁率

表一2 白川石以外の石材と判断された石仏の帯磁率

\begin{tabular}{|c|c|}
\hline 石材 & 帯磁率の測定値（単位 : $\left.10^{-3} \mathrm{SI}\right)^{*}$ ) \\
\hline $\mathrm{A}$ 花崗閃緑岩 & $0.223, \quad 0.245, \quad 0.313,0.332$ \\
\hline B 花崗閃緑岩 & $7.50,8.26,9.28,9.84,10.40,11.70$ \\
\hline C 斑レイ岩 & $0.544,0.579,0.840,1.00,1.13$ \\
\hline D 砂岩 & 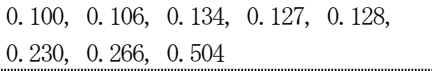 \\
\hline E 花崗岩 & $1.51,1.59,1.80$ \\
\hline $\mathrm{F}$ 花崗閃緑岩 & $0.318,0.489,0.620$ \\
\hline G チャート & $0.029,0.042$ \\
\hline
\end{tabular}

石造物が消失しつつある今日，京都の石の文化を捉えるには，石 仏は有効な指標の一つといえよう。また, 本研究の調査範囲では, 他地域に多くみられる馬頭観音や庚申塔 15,18$)$ がなく，ほとんどが 石仏であることから，川勝氏が指摘した阿弥陀如来坐像の石仏が 顕著に多いといら京都の特色らについて検証できた。

次に，1800 体以上の石仏は白川石の石仏と判断され，白川石の 産地から離れた大原, 岩倉, 静市を含め, 広く分布していることが 分かった。このことから，川勝氏が指摘した京都の花崗岩製の石 仏は，少なくとも本研究の調査範囲において，ほぼすべてが白川 石製のものであると考えられる。また, 北東部の大原, 東部の一乗 寺から吉田，南部の岡崎と南禅寺まで，いずれも白川石の石仏が 多数存在していたことから，白川石の石仏の分布範囲は本研究の 15 エリアを超えていると考えられる。その一方，鞍馬では，白川 石の石仏の数が少なく，他の石材が多く使われていた。この結果 により，鞍馬が白川石の石仏の分布範囲の境界の一つであること が示唆される。今後は調査範囲を広げ，白川石の石仏の分布範囲 の全体像を解明することが課題となる。

以上から, 白川石は, 京都盆地内の石仏製作用の石材としても強 い影響力を有することが認められた。一方，白川石以外の石材で 作られた石仏は 90 体のみであり，1～2 体で散在していることか ら，京都市左京区山麓部において，白川石以外の岩石は石仏の製 作では，広範囲に利用されていないことが分かった。白川石は京 都盆地の他の石材に比へ，産量が豊富であり，石質は軟らかくて 粘りがあり，石造物の彫刻がしや寸く 20-21)，高度な石工技術を持 っていない村人でも石仏を製作することが可能であったと推測さ れる。次に, 白川石は明度が高く, 白黒が鮮明であり 3), その白色 は清净，神聖を連想させる ${ }^{23)}$ た，白川石を砕いて作った白川砂 は京都の寺社や庭園に敷か氺ていた 1,2,23)。安定な産量と加工の利 便性，優れた白色がもたらす美観性，そして浄土信仰に深く関わ る比㪍山の周辺の産出という産地の宗教性は，白川石が京都の阿 弥陀如来像の製作に多く使われた要因であると考えられる。

その他の石材として，大原と八瀬では花崗岩閃緑岩の石仏が確 認され，その中に古い時代の作とみられる大きな石碑仏もあった。 この花崗閃緑岩は比頕山の北から産出したものであると推測され る (図-1)。なお, 貴船地域の花崗岩 1 体の帯磁率は白川石の約 10 倍を示していた。白川石は京都盆地を囲む山から産出する唯一 の花崗岩であるため, これは京都盆地以外の石材と推定される。 調査範囲に散在する灰色, 黒色, 赤色の砂岩と茶色のチャートは, 京都盆地の北山と東山に多く存在する砂岩やチャートの地帯から 


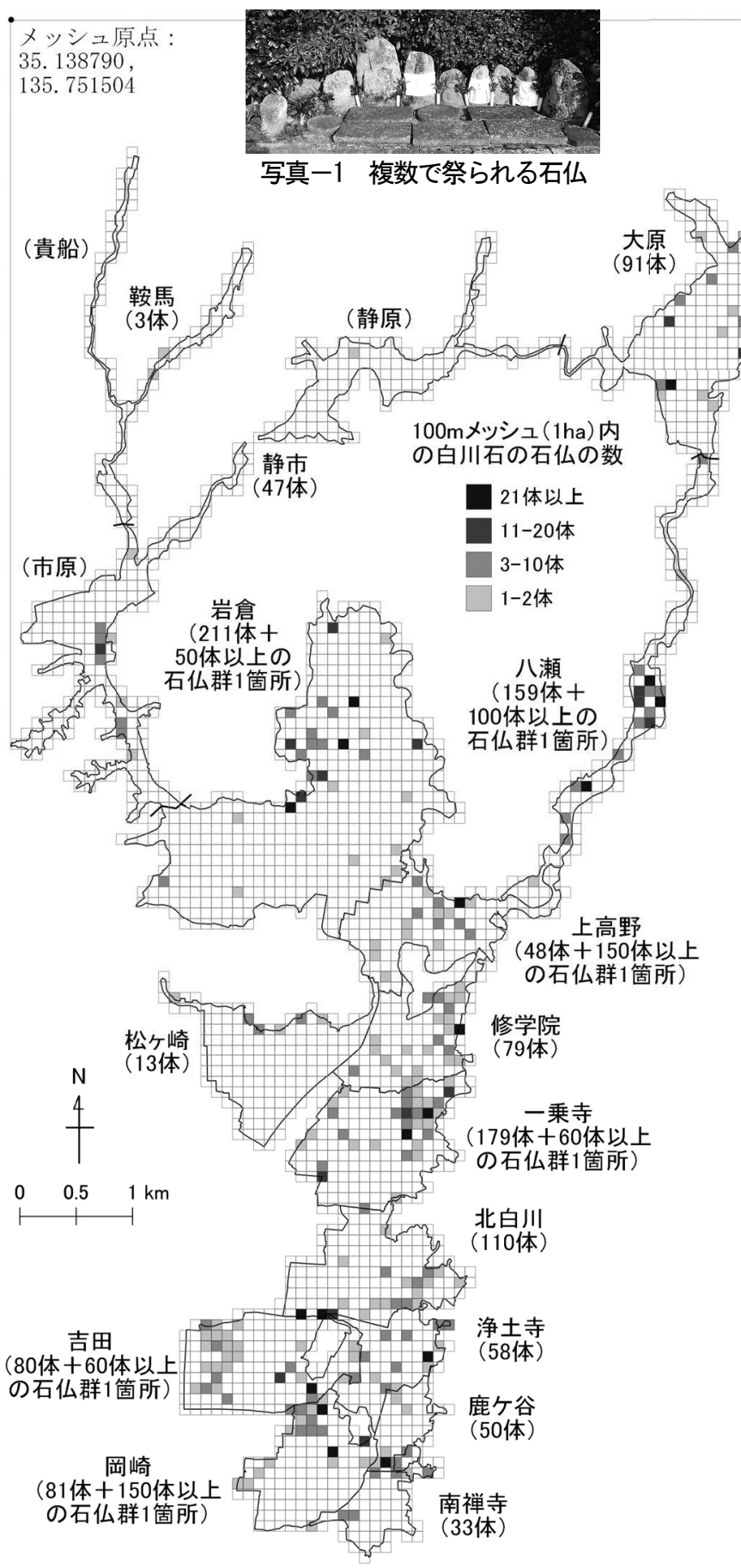

図-3 白川石と判断された石仏の密集状況

採取したものと推測される。しかし, 以上は推定までに留まり, 今 後は京都盆地周辺の山から採取したサンプルと照合し，石仏に使 われる白川石以外の石材の産地を判明寸ることが必要となる。

石仏を切口として京都の石の文化をさらに解明するには, 他の 視点からアプローチ寸るのも重要であろう。本研究で確認された 膨大な数の白川石の石仏は, 製作年や由来に関寸る銘文が一切な かったが，楕円形の阿弥陀如来坐像から細長い板碑仏まで様々で あったため, 石仏の造形から異なる時代の社会や宗教の背景を追 求することが可能であろう。また，京都の石仏が道沿いに祭られ た経緯について, 既往研究 4,11)では, 近代以降の道路工事, 宅地整 備, 田畑や井戸から出土した事例が複数報告されている。本研究 でも, 山際や封完に 1 箇所大量に集められる事例や, 住宅地化さ れたかつての水田地に散在している事例が確認された。今後は石
表一3 1ha における白川石と判断された石仏の数

\begin{tabular}{|c|c|c|}
\hline 1 グリッド内の & グリッド & $\begin{array}{c}\text { グリッドの数が } \\
\end{array}$ \\
\hline 石仏の数 & の数 & 257 グリッドに占める割合 \\
\hline 51 体以上 & 5 & $1.95 \%$ \\
\hline 21-50 体 & 13 & $5.06 \%$ \\
\hline 11-20 体 & 18 & 7. $00 \%$ \\
\hline 6-10 体 & 33 & $12.84 \%$ \\
\hline 3-5 体 & 58 & $22.57 \%$ \\
\hline 2 体 & 41 & $15.95 \%$ \\
\hline 1 体 & 89 & $34.63 \%$ \\
\hline
\end{tabular}

仏に関する詳細な聞き取り調査を行うことで，白川石の石仏の由 来や移設の歴史, 密集状況のばらつきが発生した要因を把握する ことが今後の課題になる。

謝辞：本研究は、日本私立学校振興・共済事業団の 2020 年度女 性研究者奨励金 (代表: 張平星) の助成より実施されたものである。

\section{補注及び引用文献}

1）小林章 (1982)：造園材料としての白川砂の研究 : 造園雑誌 46(2), 102-115

2）張平星ほか (2015) : 京都の寺院における白川砂の利用と維持管理 : ランド スケープ研究 78(5)，497-500

3）張平星ほか (2017)：造園材料としての白川石およひ類似花崗岩の色彩的特 徵の分析 : ランドスケープ研究 81(5)，467-472

4) 張平星ほか (2019) : 京都東山北部山麓の 3 集落の町並多に現存する白川石 の石造物と石垣 : ランドスケープ研究 82(5), 635-638

5）川勝政太郎（1972）：京都の石造美術，木耳社,11-56

6）尼㠃博正 (2002) : 庭石と水の由来 日本庭園と石質と水系, 昭和堂, $324 \mathrm{pp}$

7）村上忠喜 (2018)：「地蔵盆」に関するアンケート調查結果, 京都市文化財保 護課研究紀要 創刊号, 114-129

8）近藤無滴ほか (2014）：時空間情報を用いた京都における「お地蔵さん」・地 蔵盆の分析, 情報処理学会研究報告 102(8), 1-8

9）竹内泰・布野修司（1999）：京都における地蔵の配置に関する考察，日本建 築学会計画系論文集 $520,263-270$

10) 井上学ほか (2007) : 文化財フィールト調查におけるモバイル GIS (POS システム) の有用性，じんもんこん 2007 論文集，95-100

11）長尾智子ほか (2002)：近代京都における地蔵安置の変遷, 日本建築学会近 畿支部研究報告集 7002, 485-488

12）佐藤弓隆（2015）:京都市伏見区における路傍祠の分布と地域住民によるの 管理，民俗建築 (148), 38-43

13）清水邦彦 (2011）: 路傍の地蔵の歴史的考察, 宗教研究 84(4),340-341

14）「角川日本地名大辞典」編纂委員会（1982）: 角川日本地名大辞典 26 京都 府下巻, 角川書店, $838 \mathrm{pp}$

15）谷口興紀ほか（2004）：GIS を用いた河内長野市における路傍泀に関する研 究、日本都市計画学会都市計画論文集 39(1), 31-40

16）小坂和夫 (1998) : 応用地質の調查における带磁率の利用法, 応用地質 39(3), 208-216

17）森尻理恵・中川充（2015）：磁化率（magnetic susceptibility）をめぐる雑 感，GSJ 地質ニュース 4(12), 337-345

18）池田佳和ほか（2003）:都市における民俗信仰有形物にまつわる管理及び活 動に関する実証的研究 東京都目黒区を事例として, 日本都市計画学会都市 計画論文集 38(3), 871-876

19） 15 エリアの石仏の分布に影響寸る明確な地点がないため,メッシュの作成は QGIS (ver3.4.8)の「グリッドの作成了機能を利用した (EPSG:2448)。QGIS は自動的に, 15 エリアの最北端から南一, 最西端から東ヘメッシュを作成し たため,メッシュ原点の座標は 35.138790, 135.751504 となる (図一-3)。

20）臨時議院建築局（1921）: 本邦産建築石材，三菱会社，50,56-60

21）上原敬二 (1955)：庭石と石組，加島書店，92

22) 飯島亮・加藤栄一 (1978) : 原色日本の石 産地と利用, 大和屋出版, 118-121 23）進士五十八 (2005)：日本の庭園・造景の技とこころ：中公新書，111

(2020. 9. 26受付 , 2021. 3. 30受理) 